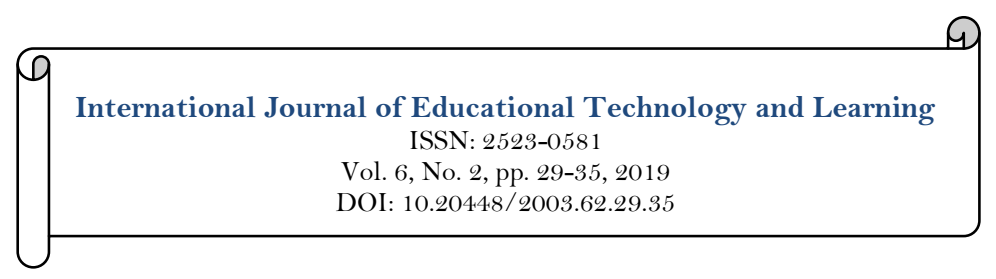

\title{
The Work of SAVI Model, Direct Learning Model and Learning Motivation to Increase
} Learning Outcome for Elementary Students

\author{
Della Malaya Putri ${ }^{2}$ \\ Ibut Priono Leksono ${ }^{2}$ \\ Abd. Cholid ${ }^{3}$
}

'Department of Educational Technology, Graduate Program, Universitas PGRI Adi Buana, Surabaya, Indonesia. Email:_ellamalava@gmail.com

${ }_{2, s}$ Graduate Program, Universitas PGRI Adi Buana, Surabaya, Indonesia.

\begin{tabular}{l|l}
\multicolumn{3}{c}{ Abstract } \\
It is found that most students from rural areas facing learning difficulties. & Keywords: \\
Based on these problems, researchers are encouraged to examine the student & SAVI model \\
learning outcomes using SAVI learning models and direct learning models, & Directlearning model \\
and want to see the differences in learning outcomes between students who & Learning motivation \\
have high and low learning motivation. The applied learning model is & Learning outcome \\
adapted to the characteristics of students by using concrete objects as media in & \\
learning activities, as wents. \\
applied to the students of State Elementary School (SDN) Sidoharjo 1 and & Licensed: \\
State Elementary School (SDN) Pagerluyung 1 Mojokerto grade 6 related to & Creative Commons Attribution 4.0 \\
science learning. The results of the study show that there are differences in & License. \\
learning outcomes between students who use the SAVI learning model and the & Publisher: \\
Direct learning model and are combined with high or low student learning & Scientific Publishing Institute \\
motivation. The application of the SAVI learning model with high learning & \\
motivation resulted in an average value of 87.581, while the average value of & Accepted: 9 September 2019 \\
the results of the application of the direct learning model which was also & Published: 17 September 2019 \\
accompanied by high learning motivation reached 84.643. The use of the & \\
SAVI model shows higher learning outcomes than the direct learning model. &
\end{tabular}

Funding: This study received no specific financial support.

Competing Interests: The authors declare that they have no competing interests.

\section{Introduction}

Education is an important pillar of the development of the nation and state. At present, many countries are competing to improve the quality of their education. The quality of education is a major problem that must be addressed immediately in determining the direction of the country's development policy. To get the state development to run well thereore qualified graduates are needed, meaning that they are able to build themselves, their families, communities, nations, and countries. Quality graduates are those who have high quality human resources and able to compete with other countries.

The government has tried various ways to improve Indonesia's human resources, one of which is curriculum change. The curriculum is very important in education, therefore its preparation should not be done carelessly and requires a strong foundation based on the results of deep thought and research process (Reksoadmojo in Sufairoh (2016)). The preparation of a curriculum that is not based on a strong foundation, it will have fatal consequences on educational failure. Even the compiled curriculum still needs revision or improvement to improve the quality of education, so that it can produce high-quality graduates.

The development of the era accompanied by the development of science and technology, also become one of the factors driving the development of the curriculum in Indonesia. At present, the 2013 Curriculum has been implemented as a development of the previous curriculum, namely Competency Based Curriculum 
(Kurikulum Berbasis Kompetensi/KBK) and Education Level Curriculum (Kurikulum Satuan Tingkat Pendidikan/KTSP), which includes the integration of competency of attitudes, knowledge, and skills (Ministry of Education and Culture, 2014). Curriculum development has positive and negative effects on teachers and students.

One example of the negative impacts that arise and is experienced by students is learning difficulties. Such problems are experienced by many students, especially for elementary school students in rural areas. This problem is also experienced by students of SDN Sidoharjo 1 and SDN Pagerluyung 1 Mojokerto related to science learning. A lot of material that is difficult for students to understand. This is based on the results of the analysis of the learning outcomes of class VI students who are still low. When they are given problems, students tend to have difficulty finding the answers. Such problems arise because of several causes, such as: monotonous strategies, methods, approaches, and learning models. Many teachers who teach only by the lecture method, without providing practical or experimental activities. All material is only explained verbally, rarely using media or other learning facilities. Many demands and training that require teachers to be more creative and innovative in teaching, but many also refuse to apply it for reasons of limited funds, as well as the condition of schools that do not have complete facilities.

Based on the above problems, researchers are encouraged to study the difference in improving student learning outcomes using SAVI learning models and direct learning models, and want to see the differences in learning outcomes between students who have high and low learning motivation. The applied learning model is adapted to the characteristics of students by using concrete objects as media in learning activities, as well as in experimental activities Meier (2004) states that students can combine physical movements with intellectual activity and the use of all senses that can have a major influence on learning. Thus, using the SAVI learning model is expected to be able to improve student learning outcomes.

Whereas in applying the Direct Learning model, students are explained about concepts related to learning material without going through the SAVI steps. However, basically both of these learning models are applied to improve student learning outcomes. In addition, the application of these two learning models are combined with increasing student motivation, so that students can obtain basic science, concepts, and skills. A study by Sari, Sulistiasih, and Sudirman (2015) confirms that SAVI learning model with the right steps can improve learning activities and student learning outcomes in each cycle. The study was the Classroom Action Research model which was applied to fifth grade students of SDN 2 Notoharjo. Another study by Elistiana (2016) states that the learning model can directly improve the learning outcomes of fifth grade students of SDN Basi, Tolitoti through Classroom Action Research. In different study by Indriani (2014) states that there is an influence between learning motivation of class V students on Mathematics learning achievement at Bejirejo Elementary School, Blora. This research is classified as comparative causal research which investigates the possibility of causal linkages through observation activities.

From the previous elaboration, therefore this research addresses to three problems: 1) the differences in science learning outcomes between students who study using the SAVI learning model with direct learning models, 2) the differences in science learning outcomes between students who have high learning motivation and students who have low learning motivation, and 3) the interactions between the SAVI learning model, the direct learning model, and learning motivation towards the learning outcomes of science subject.

\section{Research Method \\ 2.1. Research Design}

The design used in this study is quasi-experimental or quasi-experimental, which is essentially the same as true experiment. However, in quasi-experiment researchers do not have the flexibility to manipulate research subjects, meaning random groups are usually used as a basis for setting treatment groups and control groups (Setyosari, 2016). Specifically, this research is referred to as True Experimental Design, with the design of the Control Group Pre-Test - Post-Test. The research was designed as follows:

Table-1. Learning model.

\begin{tabular}{l|c|c|c}
\hline \multicolumn{1}{c|}{} & SAVI $\left(\mathbf{X}_{1}\right)$ & Direct learning $\left(\mathbf{X}_{2}\right)$ \\
\hline \multirow{4}{*}{ Motivation } & High & $\begin{array}{c}\text { Learning outcome 1 } \\
\left(\mathrm{LO}_{1}\right)\end{array}$ & $\begin{array}{c}\text { Learning outcome } 2 \\
\left(\mathrm{LO}_{2}\right)\end{array}$ \\
\cline { 2 - 4 } & Low & $\begin{array}{c}\text { Learning outcome 3 } \\
\left(\mathrm{LO}_{3}\right)\end{array}$ & $\begin{array}{c}\text { Learning outcome } 4 \\
\left(\mathrm{LO}_{4}\right)\end{array}$ \\
\hline Source: Arikunto (2006).
\end{tabular}

Remark:

$\mathrm{X} 1=$ subject group given the SAVI learning model.

$\mathrm{X}_{2}=$ subject groups given direct learning models.

$\mathrm{HB}_{1} \quad=$ learning outcomes of subjects using the SAVI learning model with high learning motivation.

$\mathrm{HB}_{2}=$ subject learning outcomes using direct learning models with high learning motivation.

$\mathrm{HB}_{3}=$ learning outcomes of subjects using the SAVI learning model with low learning motivation. 
$\mathrm{HB}_{4} \quad=$ subject learning outcomes using direct learning models with low learning motivation.

The population used in this study were all students of class VI (68 students) which consisted of SDN Sidoharjo 1 (34 students) and SDN Pagerluyung 1 (34 students) Mojokerto. While the sample used in this study was the sixth grade students of SDN Sidoharjo 1 and the sixth grade students of SDN Pagerluyung 1 Mojokerto. The sample selection was done by total sampling technique because the total population was only 68 students and had not reached 100 students. In addition, sample selection is also based on the characteristics of students who are on average 10-12 years old. According to Piaget in Yusuf (2005) the thinking power of children at this age has developed in the direction of concrete and rational thinking (acceptable to reason). Piaget named it a concrete operational period, namely the end of imaginary thinking and begin to think concretely (relating to the real world).

Class VI elementary school students already have various skills that can develop their mindset and reasoning power, so they can understand the subject matter they have received, and can explain the content of the material that has been taught in their own sentence. Therefore, the application of the SAVI learning model is in accordance with the characteristics of students. So that it is expected that the students who are sampled will be able to follow and implement the stages of the SAVI learning model that can make students more active by involving all five senses to follow the entire series of learning processes.

\subsection{Research Steps}

The steps taken by the researcher in this research activity consisted of four stages, namely: 1) Phase I (Planning), covering activities: a) the researcher designed the class to be sampled; and b) researchers make research instruments that will be used for research; 2) Phase II (Implementation), includes activities: a) researchers/teachers carry out learning in the experimental group by applying the SAVI learning model, and in the control group using the direct learning model strategy; and b) researchers carry out trials, analyze and establish research instruments in the form of learning motivation questionnaires; 3) Phase III (Evaluation of learning outcomes), by evaluating learning outcomes, analyzing or processing data that has been collected with predetermined methods; and 4) Stage IV (Preparation of reports) with activities to compile and report the results of the research activities that have been carried out.

\subsection{Technique of Data Collection}

The data collection methods used in this study were consisted of: 1) Test techniques, which were carried out by giving a test to each student to obtain data on science learning outcomes in class VI SDN Sidoharjo 1 and SDN Pagerluyung 1 Mojokerto using learning strategies in the form of SAVI learning model and direct learning model; and 2) Questionnaire technique, which is done by giving a questionnaire to each student to obtain data about the learning motivation possessed by students when they take science learning to class VI students at SDN Sidoharjo 1 and SDN Pagerluyung 1 Mojokerto.

\subsection{Research Instrument}

The research instruments compiled are based on data collection methods, namely as follows: 1) Analysis of the validity of the questionnaire, can be known by using the product moment correlation formula, which was discovered by Karl Pearson and used to describe the relationship between two variables which are of the same type of interval or ratio. To calculate the product moment correlation coefficient can use the following formula:

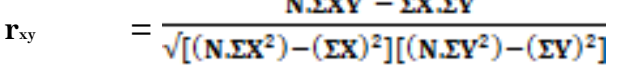

(Winarsunu, 2009) with the the requirement that if $r$ empiric $\geq r$ is theoretical, the correlation is significant. Whereas if $\mathrm{r}$ empirical $<\mathrm{r}$ theoretical means the correlation is not significant; and 2) questionnaire reliability analysis, can be searched using Alpha formula as follows:

$$
\begin{aligned}
& \mathrm{r}_{11}=\left[\frac{\mathbf{k}}{(\mathrm{k}-1)}\right]\left[1-\frac{\Sigma \sigma \mathrm{b}^{2}}{\sigma^{2} \mathrm{t}}\right], \\
& \mathrm{r}_{11}=\text { questionnaire reliability. } \\
& \mathrm{k}=\text { the number of questions. } \\
& \Sigma \sigma_{\mathrm{b}}{ }^{2}=\text { number of item variants. } \\
& \sigma^{2} \mathrm{t}=\text { total variant. }
\end{aligned}
$$

(Arikunto, 2006)

\subsection{Technique of Data Analysis}

The data analysis technique used in this study uses two-way ANOVA analysis with the help of SPSS (Statistical Product and Service Solution) application version 24. The statistical program used to analyze this data is the Kolmogorof test and Levense test. The analysis technique includes two things, namely: 1) Test for normality, carried out to find out whether the data on student learning outcomes and students' learning 
motivation spreads follow the curve or not. The normality test in this study uses the rule that if $\mathrm{p}>0.05$, then the distribution is declared normal. And if $\mathrm{p}<0.05$, the distribution is declared abnormal; 2) Homogeneity test, needed to test the similarity (homogeneity) of several parts of the sample, namely the uniformity of whether or not variants of samples taken from the same population.

This step is used to answer the hypothesis by using a two-way Variant Analysis (Anava) with a significance level of $5 \%$, using the ratio calculation formula as follows:

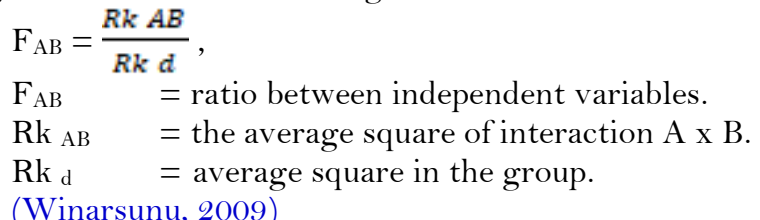

If there is a difference in price $(\mathrm{F}<0.050)$ then it is declared significant or heterogeneous. If there is no difference $(\mathrm{F}>0.05)$ then it is not significant or homogeneous.

\subsection{Data Analysis}

The data analysis technique used is the Two Way Anova test to answer a number of problem statements. Analysis of the data used includes parametric statistical tests that must meet the prerequisite test in the form of a normality test and a homogeneity test. The significance level used in this study is 0.05. This prerequisite test aims to determine whether there are any deviations from the determined variables. The following is a description of the intended prerequisite test, namely: 1) Test for normality, in this study using KolmogorovSminorv One-Sample technique. To find out whether the data is normal or not, it can be seen from the value of p calculated on each variable studied. With testing criteria, if indigo asymp.sig (2-tailed) $\geq 0.05$ then the data is normally distributed. Conversely, if the asymp.sig (2-tailed) value is 50.05 , then the data is not normally distributed. The results of the normality test in this study can be seen in Table 2.

Table-2. One sample Kolmogorov-Sminorv technique.

\begin{tabular}{l|l|c|c|c|c}
\hline \multicolumn{2}{l|}{} & $\begin{array}{c}\text { Learning } \\
\text { model }\end{array}$ & $\begin{array}{c}\text { Pre-Test } \\
\text { result }\end{array}$ & $\begin{array}{c}\text { Post-Test } \\
\text { result }\end{array}$ & $\begin{array}{c}\text { Learning } \\
\text { motivation }\end{array}$ \\
\hline $\mathrm{N}$ & & 68 & 68 & 68 & 68 \\
\hline Normal & Mean & 1.50 & 63.38 & 84.49 & 73.97 \\
\hline Parameters, $\mathrm{b}$ & Std. deviation & .504 & 7.250 & 7.971 & 4.983 \\
\hline Most & Absolute & .340 & .159 & .213 & .095 \\
\hline Extreme & Positive & .340 & .135 & .213 & .095 \\
\hline Differences & Negative & -.340 & -.159 & -.125 & -.079 \\
\hline \multicolumn{2}{l|}{ Kolmogorov-Smirnov Z } & 2.800 & 1.308 & 1.758 & .783 \\
\hline \multicolumn{2}{l|}{ Asymp. sig. (2-tailed) } & .000 & .065 & .004 & .573 \\
\hline
\end{tabular}

Source: Result by SPSS 24.

Based on the results of calculations using SPSS 24 above, it was found that the asymp.ig (2-tailed) value was 0.65 and $0.573>0.05$. Similarly, the standard deviation of each variable shows a value of 50.05 , namely the learning model variable of 0.504 ; pre-test learning outcome variable is 7,250; the post-test variable is 7.971; and learning motivation variables of 4.983. So, it can be concluded that the distribution of research data is normal; 2) the homogeneity test, can be done using the Lavene Test technique, by looking at the significance level of the value of Lavene count. If the F-count value indicates a significance level of $>0.05$, it can be said that there is no difference in variance between the sample groups (variants between groups are the same). The homogeneity test results in this study in Table 3.

Table-3. Lavene test of equality of error variance. Dependent cariable:Learning outcome post-test

\begin{tabular}{c|c|c|c}
\hline $\mathbf{F}$ & $\mathbf{d f 1}$ & $\mathbf{d f 2}$ & Sig. \\
\hline 2.150 & 3 & 64 & .103 \\
\hline
\end{tabular}

Based on the table above, the results of the homogeneity test show that the Lavene value of the variable learning outcomes and the results of the learning motivation questionnaire in the control class and experimental class shows a significance level of $0.103>0.05$. So that it can be concluded that there is no difference between the sample groups, because the variance between the variables of the science learning outcomes group and the results of the motivation questionnaire scores are the same or homogeneous. 


\subsection{Interpretation of Hypothesis Testing}

After the researcher conducts the prerequisite test, then the next step is to analyze the data to test the hypothesis. The step that needs to be done is a two-way covariance analysis test, because the learning outcome variable meets the assumption of normality.

The following will be presented in the calculation results using the SPSS 24 application of two-way covariance analysis techniques, namely:

Table-4. Tests between subjects effects.

\begin{tabular}{c|c|c|c|c|c}
\hline \multicolumn{7}{c}{ Dependent variable: Learning outcome } \\
\hline Source & Type III sum of squares & df & \multicolumn{1}{c}{ Mean square } & F & Sig. \\
\hline Corrected model & $688.434^{\mathrm{a}}$ & 3 & 229.478 & 4.116 & .010 \\
\hline Intercept & 358026.243 & 1 & 358026.243 & 6421.003 & .000 \\
\hline Learning & 102.611 & 1 & 102.611 & 1.840 & .018 \\
\hline Motivation & 256.584 & 1 & 256.584 & 4.602 & .036 \\
\hline Learning motivation & 90.227 & 1 & 90.227 & 1.618 & .028 \\
\hline Error & 3568.552 & 64 & 55.759 & & \\
\hline Total & 489625.000 & 68 & & & \\
\hline Corrected total & 4256.985 & 67 & & & \\
\hline $\begin{array}{l}\text { a. R Squared }=.162(\text { Adjusted R squared }=.122) . \\
\text { Source: Result by SPSS 24. }\end{array}$
\end{tabular}

Using data such as mentioned in Table 4 previously, the analysis can be used to test hypotheses 1, 2 and 3 as follows: 1) Hypothesis 1, the significance level of the corrected model is 0.010 which is less than 0.050. So it can be concluded that $\mathrm{Ho}$ is rejected and $\mathrm{Ha}$ is accepted. That is, there are differences in science learning outcomes between groups of students whose learning uses the SAVI learning model with groups of students whose learning uses direct learning models in class VI SDN Sidoharjo 1 and Pagerluyung 1 Elementary School Mojokerto; 2) Hypothesis 2, the significance level of learning motivation is 0.036 which is less than 0.050. So it can be concluded that Ho is rejected and $\mathrm{Ha}$ is accepted. That is, there are differences in science learning outcomes between groups of students who have high learning motivation with groups of students who have low learning motivation in class VI SDN Sidoharjo 1 and Pagerluyung 1 Elementary School Mojokerto; and 3) Hypothesis 3, the significance level of the interaction between the learning model and learning motivation is 0.028 which is less than 0.050. So it can be concluded that Ho is rejected and Ha is accepted. That is, there is an interaction between the SAVI learning model, direct learning model, and learning motivation towards the learning outcomes of science in class VI SDN Sidoharjo 1 and Pagerluyung 1 Elementary School Mojokerto.

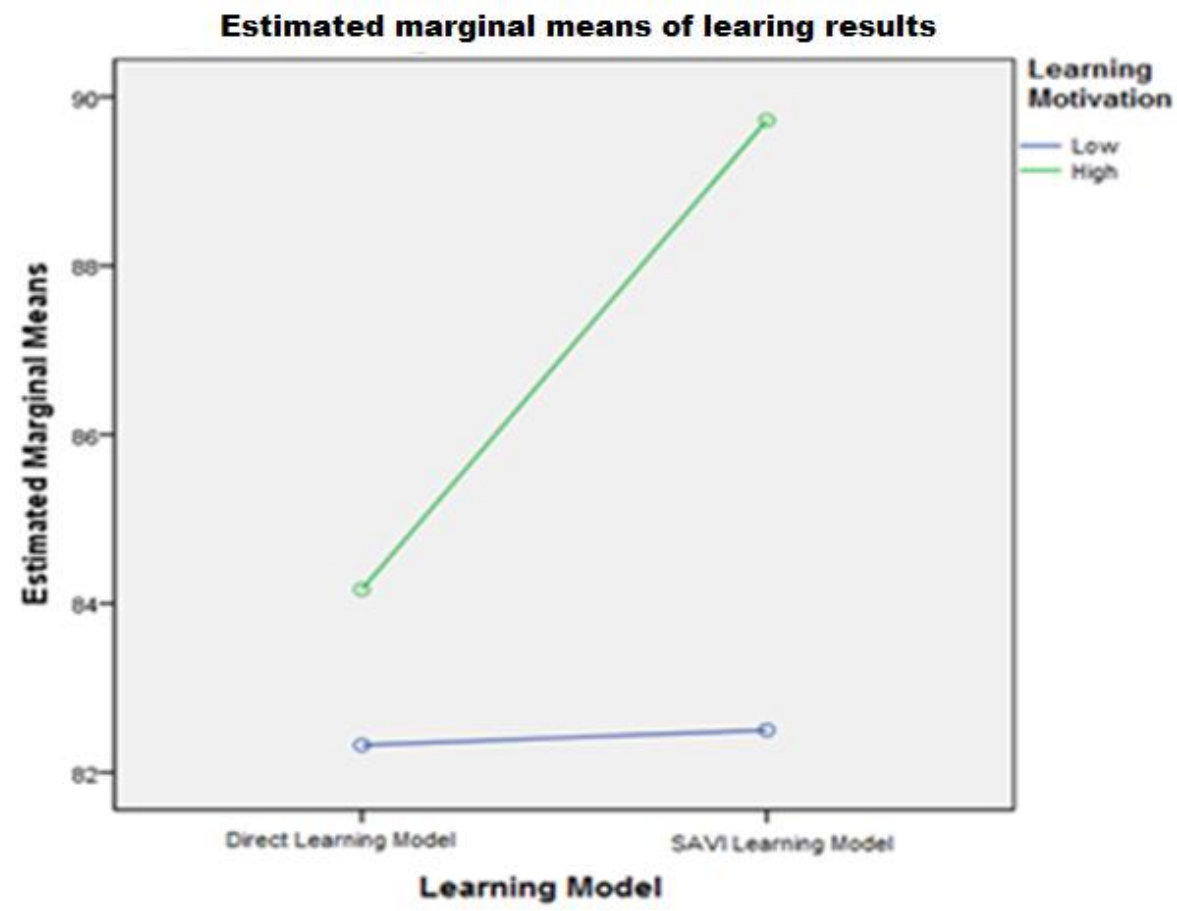

Figure-1. Learning result of science subject reviewed from learning model. Source: Result by SPSS 24 . 


\section{Results and Analysis}

3.1. Differences in Science Learning Outcomes between Students Using the SAVI Learning Model and Direct Learning Models in Class VI Students of SDN Sidoharjo 1 and SDN Pagerluyung 1 Mojokerto

Based on the results of research and data analysis tests on the first hypothesis which reads: "there are differences in science learning outcomes between groups of students whose learning uses SAVI learning models with groups of students whose learning uses direct learning models in class VI SDN Sidoharjo 1 and SDN Pagerluyung 1 Mojokerto" shows that the SAVI learning model has more influence on student learning outcomes.

Table-5. Science learning result reviewed from SAVI and direct learning model.

\begin{tabular}{c|c|c|c|c}
\hline \multirow{2}{*}{ Learning model } & \multirow{2}{*}{ Mean } & \multirow{2}{*}{ Std. error } & \multicolumn{2}{|c|}{$\mathbf{9 5 \% \text { Confidence interval }}$} \\
\cline { 4 - 5 } & & & Lower bound & Upper bound \\
\hline Direct learning & 78.988 & 1.498 & 75.995 & 81.981 \\
\hline SAVI model & 80.457 & 2.014 & 76.434 & 84.48 \\
\hline
\end{tabular}

This can also be seen from the average value of student learning outcomes which states that the SAVI learning model reaches an average of 80.457 (complete) and student learning outcomes with a direct learning model reaches an average of 78.988 (complete). Although both are complete, but from these results indicate that the SAVI learning model is more dominant in improving student learning outcomes.

This condition can be due to the application of the SAVI learning model, students are more active in activities through practical activities. In accordance with the RPP that has been prepared, student activities carried out involve all the senses, ranging from seeing, listening, doing motor activities, and thinking of working on test questions. So, when the SAVI learning model takes place, the teacher can also apply the four SAVI components which include: 1) Somatic, when students carry out practical activities observing the parts of the flower. They work actively in groups by involving body movements; 2) Auditory, when students listen to the teacher's explanation or when listening to the opinions of group friends during the discussion; 3) Visual, when students see parts of flowers using their sense of sight; and 4) Intelectual, when students answer questions related to activities and lab results. Or happens when students can answer the pre-test questions.

Hamalik (2007) states that learning is not only remembering, but more broadly than that, namely experiencing. The learning experience with the SAVI model conducted by students will be more remembered as an experience, so that it can improve learning outcomes. Whereas in applying the direct learning model, the teacher only uses picture media without practical activities, so that it only involves students in several components, such as: seeing, listening, and thinking.

3.2. Differences in Science Learning Outcomes between Students Who Have High Learning Motivation and Low Learning Motivation in Class VI Students of SDN Sidoharjo 1 and SDN Pagerluyung 1 Mojokerto

Table-6. Science learning result reviewed from learning motivation.

\begin{tabular}{c|c|c|c|c}
\hline \multirow{2}{*}{ Learning model } & \multirow{2}{*}{ Mean } & \multirow{2}{*}{ Std. error } & \multicolumn{2}{|c}{ 95\% Confidence interval } \\
\cline { 3 - 5 } & & & Lower bound & Upper bound \\
\hline Low & 73.333 & 2.355 & 68.628 & 78.038 \\
\hline High & 86.112 & 0.868 & 84.377 & 87.847 \\
\hline
\end{tabular}

Source: Result by SPSS 24 .

Based on the results of research and data analysis testing of the second hypothesis which reads: "There are differences in learning outcomes between groups of students who have high learning motivation with groups of students who have low learning motivation in class VI SDN Sidoharjo 1 and Pagerluyung 1 Elementary School Mojokerto" shows that students who have high learning motivation will achieve high learning outcomes too, and conversely students who have low learning motivation will find it difficult to achieve maximum learning outcomes.

Hanafih and Cucu (2010) state that motivation to learn is power (motivation), driving force, or a tool to build a willingness and strong desire in students to learn actively, creatively, effectively, innovatively, and pleasantly in the framework of behavior change, both cognitive, affective, and psychomotor.

In Table 6 it can be seen that Science learning outcomes between students who have high learning motivation are indeed superior with an average score of 86,112 when compared with the science learning outcomes of students who have low learning motivation whose average score only reaches 73,333 . Students who have high learning motivation tend to be easy to master learning material when compared to students who have low learning motivation. 
3.3. There is an Interaction between SAVI Learning Model, Direct Learning Model, and Learning Motivation to Science Learning Outcomes in Class VI Students of SDN Sidoharjo 1 and SDN Pagerluyung I Mojokerto

Table-7. Science learning outcome after the interaction of learning model and learning motivation.

\begin{tabular}{c|c|c|c|c|c}
\hline \multirow{2}{*}{ Learning model } & \multirow{2}{*}{$\begin{array}{c}\text { Learning } \\
\text { motivation }\end{array}$} & \multirow{2}{*}{ Mean } & Std. error & \multicolumn{2}{c}{ 95\% Confidence interval } \\
\hline \multirow{2}{*}{ Direct learning } & Low & 73.333 & 2.720 & 67.900 & 78.766 \\
\cline { 2 - 6 } & High & 84.643 & 1.259 & 82.128 & 87.158 \\
\hline \multirow{2}{*}{ SAVI model } & Low & 73.333 & 3.846 & 65.650 & 81.017 \\
\cline { 2 - 6 } & High & 87.581 & 1.196 & 85.191 & 89.971 \\
\hline
\end{tabular}

Source: Result by SPSS 24 .

Based on the results of research and testing data analysis data on the third hypothesis which reads: "There is interaction between SAVI learning models, direct learning models, and learning motivation towards science learning outcomes in class VI SDN Sidoharjo 1 and SDN Pagerluyung 1 Mojokerto" there are interactions.

The results of the research process in the field as can be seen in Table 7 prove that there is a significant influence on the achievement of learning outcomes using the SAVI learning model and direct learning model, as well as high or low learning motivation. This result is evidenced by the average results of students who have high learning motivation using the SAVI learning model reaching a value of 87.581 and superior to the results of the average score of students who have high learning motivation using the direct learning model which reached 84.653 (lower).

\section{Conclusion}

Based on the findings in the field and the results of data analysis, the researcher can make conclusions related to the results of this study. The conclusions of this study are as follows: 1) There are differences in science learning outcomes between groups of students whose learning uses the SAVI learning model with groups of students whose learning uses direct learning models in class VI SDN Sidoharjo 1 and SDN Pagerluyung 1 Mojokerto; 2) There are differences in science learning outcomes between groups of students who have high learning motivation and groups of students who have low learning motivation in class VI SDN Sidoharjo 1 and SDN Pagerluyung 1 Mojokerto; and 3) There is an interaction between the SAVI learning model, the direct learning model, and learning motivation towards the learning outcomes of science in the sixth grade students of SDN Sidoharjo 1 and SDN Pagerluyung 1 Mojokerto.

\section{References}

Arikunto, S. (2006). Research procedure. Jakarta: Rineka Cipta: A practical approach.

Elistiana. (2016). Application of image assisted direct instruction model to improve student learning outcomes in science subjects in Class V SDN 5 Basi Basidondo Tolitoli District Creative Journal Tadulako Online, 4(9), 148-159.

Hamalik, O. (2007). Teaching and learning process. Jakarta: Earth Literacy.

Hanafih, N., \& Cucu, S. (2010). Learning strategy concepts. Bandung: Refika Aditama.

Indriani, A. (2014). The effect of class V student learning motivation on mathematics learning achievement in Bejirejo elementary school, Kunduran District, Blora Regency. Journal JIPM of IKIP PGRI Bojonegoro, 4(2), 134-139.

Meier, D. (2004). The accelerated learning handbook. Bandung: Kaifa.

Ministry of Education and Culture. (2014). Teacher training materials: Implementation of 2013 curriculum for elementary school V. Jakarta: Ministry of Education and Culture.

Sari, I. F., Sulistiasih, S., \& Sudirman, A. (2015). Application of the SAVI model to increase science learning activities and outcomes. Journal of Pedagogy, 3(4), 1-10.

Setyosari, P. (2016). Educational research and development methods. Jakarta: Prenada Media.

Sufairoh. (2016). Scientific approach \& learning model K-13. Journal of Professional Education, 5(3), 116-125.

Winarsunu, S. (2009). Statistics in psychology $\Xi^{2}$ education research. Malang: UMM Press.

Yusuf, S. (2005). Child ङं adolescent developmental psychology. Bandung: Teen Rosdakarya. 